\title{
Differences in Reading Comprehension Text Reading Skills by Using Auditory, Intellectually, Repetition (AIR) and Brainstorming Learning Models in Terms of Students Reading Interest
}

\author{
Dia Fitri $^{1 *}$, Erizal Gani ${ }^{2}$ \\ Faculty of Languages and Arts, Masters Study Program, Indonesian language and literature education, Universitas \\ Negeri Padang, Indonesia \\ *Corresponding author. Email: diafitri5@gmail.com
}

\begin{abstract}
This research aims to determine the differences of reading skills in comprehension of exposition text by using the auditory learning model, intellectually, repetition (AIR) and brainstorming in terms of students' interest in reading at VIII class of MTsN 5 Solok Selatan. Theories used in this research are reading interest, reading skill learning of exposition text, auditory learning models, intellectually, repetition (AIR) and brainstorming. This research was quantitative with the experimental method. The type of research design used was a quasiexperimental design with a factorial design. This research used three variables, namely the reading skill of exposition text as the dependent variable, auditory learning model, intellectually, repetition (AIR) and brainstorming as independent variables, and students' interest in reading as a moderator variable. The sample in this research amounted to 64 (experimental classes I and II each amounting to 32 people) which taken by using purposive sampling. The data in this study were scores on reading interest and scores on the reading skill of exposition text in both sample classes. There were four results of this research. First, there was no significant difference in the reading skill of exposition text between students who were taught by using auditory, intellectually, repetition (AIR) learning models and students who were taught with a brainstorming learning model. The average comparison of both classes was 86.30 and 85.02. Secondly, there was no significant difference in reading skill of exposition text between students who have high reading interest who were taught with auditory learning model, intellectually, repetition (AIR) and students who have high reading interest which taught with brainstorming learning model, with a comparison of both averages the classes was 91.35 and 90.70 . Third, there was no significant difference in reading skill of exposition text between students who have low reading interest who were taught with auditory learning models, intellectually, repetition (AIR) and students who have low reading interest who were taught with brainstorming learning model, with a comparison of the average the two classes was 81.23 and 79.33. Fourth, there was a significant interaction effect between the learning model and students' interest in reading toward students' reading skill on comprehension text.
\end{abstract}

Keywords: Auditory, intellectually, (AIR), brainstorming, reading exposition text skills

\section{INTRODUCTION}

Reading is not just an easy activity so students need things to support their reading comprehension. Evidenced by the use of reading teaching strategies, research conducted in countries such as the United States (Ness, 2009; Pilonieta, 2010), Australia (Morris, 1986), and Ireland (Concannon-Gibney \& Murphy, 2011) have shown that many teachers not applying reading comprehension in their classrooms. The study investigates the extent to which teachers and adolescent students do reading comprehension in learning, referenced from a German study conducted by Florian Hiller (2013, p. 3).

Reading culture is not formed by students themselves in understanding the information from the reading. An important requirement for developing a culture of reading is to accompany the field of education and learning which refers to research from Russia conducted by Lera (2016, p. 475). Many students just simply accept what is read, 
without knowing what the meaning of the text the writer wants to convey. Most students read what is printed on the pages of books or on the screen of learning media without getting meaning from the references they read in doing learning referenced from two studies from the State of Iran conducted by Hassan, Sajadeh (2013, p. 1), Alireza, Fatemeh (2015, p.1).

Reading is a process to understand the meaning of a writing and which needs attention as important matters relating to the information contained in the reading that is read because not all words in the reading are important things that must be remembered and understood (Budi, 2016, p.42 , Devi, Siti, 2018, p.76) and reading is a multilevel and interactive process in which readers build meaningful representations of texts using their schemes, which refer to research from Arabic conducted by Ahmad (2006, p. 201).

The traditional view of reading is that the reader, as a passive recipient of text information, has a large number of sub-skills that automatically apply it to understand all types of texts, which refers to research from Iran conducted by Hossein (2014, p. 31). Students are unsure of what metacognitive strategies are and how to use them. Poor readers, especially, do not know what methods are efficient for academic reading, nor do they know how to improve their reading skills, which refers to research from Iran conducted by Hossein (2014, p. 31).

Learning Indonesian in schools also requires students to have reading comprehension skills. reading comprehension is the meaning obtained from what is written on the page, they often disagree about the source of meaning. Currently the most prevalent metaphor in literature is the reading model from the bottom up, topdown, and interactively increasing understanding (Hossein, 2014, p. 315).

Auditory, intellectually, repetition (AIR) is a learning model that is similar to the somatic learning model, auditory, visualization, intellectually (SAVI) and learning visualization, auditory, kinesthetic (VAK). The steps of the AIR learning model are as follows. First, students are divided into groups, each group consisting of 4-5 members. Second, students listen and pay attention to the teacher's explanation. Third, each group discusses the material learned and writes the results of the discussion and then presents it to the class (Auditory). Fourth, when the discussion takes place, students get questions or problems related to the material. Fifth, each group thinks of how to apply the results of the discussion and can improve their ability to solve problems (Intellectually). Sixth, after finishing the discussion, students get repetition of material by getting assignments or quizzes for individuals (repetition) (Huda, 2014, p. 289, Shoimin, 2016, p. 30).

Brainstorming learning model is a method of gathering a number of ideas from a group of people in a short time (Ridwan, 2013, p. 203). Brainstorming is a technique or way of teaching that is carried out by the teacher in the classroom, by raising a problem to the class by the teacher, then students answer or express opinions, or comments so that the problem may develop into a new problem, or can be interpreted as a way to get a lot of ideas from a group of humans in a very short time (Roestyah, 2012, p. 73). Steps to the brainstorming learning model, namely 1) providing information and motivation, 2) identification, 3) classification, 4) verification, and 5) conclusion (Roestyah, 2008, p. 74-75).

Auditory learning model, intellectually, repetition (AIR) and brainstorming are expected to be able to create a more enjoyable learning atmosphere so as to increase student interest in learning. The learning process with this model provides opportunities for students to be able to provide independence and self-direction, have openness to express opinions in solving a problem and be able to respect the opinions of others.

In addition to the use of learning models, another factor that is thought to be strong enough to influence the ability to understand exposition text is students' interest in reading. Interest is a constant tendency to pay attention to and pool activities. Interest is very big influence on learning because if the lesson material learned is not observed students will not learn as well as possible, because there is no attraction for students. High or low student interest will have an impact on learning achievement (Tarigan, 2008, p. 98, Winkel, 1996, p. 51).

Interest in reading is a linguistic condition that contains two aspects. Both aspects are affective and conative aspects. Affective aspect is the desire or pleasure of someone to read, while the conative aspect is the behavior of reading itself. Conative aspect is the most important aspect compared to the affective aspect because interest in reading is not just a desire and pleasure to read, but rather a desire that is marked or terminated by the action or behavior of the desire itself (Razak, 2005, p. 79). Thus the ability to understand a student's learning will be optimal if students have a strong interest in reading, and a student who has no interest in reading in learning, will not be possible to do learning activities.

If it is related to the problem of low interest in reading comprehension text skills of VIII MTsN 5 Solok Selatan students with AIR learning models with brainstorming, it can be concluded that this model can be used to increase students 'reading interest and comprehension text skills of VIII MTsN 5 Solok students' class exposition South.

The scope of the problem in this article is limited to the use of the AIR learning model and the brainstorming of reading comprehension skills in exposition text in terms of reading interest in students of class VIII MTsN 5 Solok Selatan. Therefore, the purpose of writing this article is to describe the differences in reading comprehension skills of exposition texts by using the AIR learning model and brainstorming in terms of reading interest of students in class VIII MTsN 5 Solok Selatan.

\section{METHOD}

This type of research is quantitative research with experimental methods. This type of research design used is quasi-experimental design with factorial design. This study uses three variables, namely reading comprehension skills of exposition text as the dependent variable, AIR learning 
models and brainstorming as independent variables, and reading interest as moderator variables.

The sample in this study amounted to 64 (experimental classes I and II each amounting to 32 people) taken using purposive sampling techniques. Based on the results of normality and homogeneity testing of sample classes, the two sample groups selected in this study were class VIII. 1 as the experimental class I and class VIII. 4 as the experimental class II. From the results of testing the normality of students' daily test data using the Liliefors test, it can be seen that the experimental class I and experimental class II are normally distributed and the experimental class I and II have homogeneous variance.

The data in this study were scores of reading interest and reading comprehension scores of exposition text comprehension in both sample classes. The instruments used for data collection were non-tests and tests. Nontes is used to collect data on students 'reading interest, while tests are used to measure students' skills in reading comprehension of exposition texts. The type of nontest used was a questionnaire in the form of a scale with a range of numbers 1 to 5 . The questionnaire was used to take scores of students 'interest in reading to 31 students who were not sampled in this study and validated by experts who understood the assessment of students' interest in reading. The number of statements in the questionnaire tested was 50 items. Based on the results of the analysis of the validity and reliability of the trial questionnaire, it can be seen that from the 50 statement items contained in the questionnaire, only 40 items were valid. Invalid statement items are 10 items.

The form of the test used to measure reading comprehension skills of exposition students of VIII grade MTsN 5 Solok Selatan is an objective test. Objective tests are used to test students' skills in identifying elements in reading comprehension and the building blocks of exposition text. The objective test is validated by conducting a test run and analyzing test result data through item validity and test reliability. The objective test items tested were 50 items. Based on the results of the analysis of the validity and reliability of the tests, 39 items were obtained which were valid and reliable. Invalid questions are 11 items. From the results of the analysis of the validity and reliability of these tests, lattices and skills in reading comprehension tests of exposition text were compiled.

For the process of analyzing the questionnaire the interest in reading in this study was carried out with a sixstep analysis. An explanation of the six steps is as follows. First, read the questionnaire that students have prepared. Second, identify each statement contained in the questionnaire whether there is something that is not filled by students, if there is something that is not filled out, it is not included in the research data. Third, give a score on each questionnaire statement that has been identified. Fourth, add up the overall score statement. The fifth ranks the questionnaire scores starting from the highest score to the lowest score. Sixth, divide students' interest in reading into two groups, namely $50 \%$ the upper group and $50 \%$ the lower group (Arikunto, 2008, p. 216).
Data analysis of reading comprehension skills of research exposition texts is carried out through the following techniques. First, giving students the reading scores of exposition text comprehension test skills which consists of objective tests. Second, processing scores of reading interest and reading comprehension scores of exposition text comprehension into grades. Third, determining the average value of reading comprehension comprehension reading skills of students in class VIII MTsN 5 Solok Selatan. Fourth, interpreting reading comprehension skills of exposition texts in students based on arithmetic mean and KKM. Fifth, the results of calculations with the formula are transformed to the scale used. Sixth, make a bar chart about students' skills in reading comprehension text skills in exposition. Seventh, analyzing research data using statistical methods to see the reading comprehension skills of exposition text in eighth grade students of MTsN 5 Solok Selatan. Data were analyzed using the difference test of two averages using ttest and F-test. To determine the difference test formula of two averages, a normality and homogeneity test of the data is first performed.

\section{RESULTS AND DISCUSSION}

Differences in Reading Comprehension Reading Skills Students are taught using the AIR learning model and the Brainstorming Learning Model.

The results of research conducted on eighth grade students of MTsN 5 Solok Selatan, it is known that the AIR learning model and the brainstorming learning model are effectively used in learning the reading skills of exposition text comprehension. The average value of experimental class I and experiment II can be seen in the table below.

Table 1 Reading Skills Test Results for Exposition Text Understanding Experiment Class I and Experiment Class II

\begin{tabular}{|l|c|c|c|c|c|}
\hline Kelas & $\begin{array}{c}\text { Nilai } \\
\text { Tertinggi }\end{array}$ & $\begin{array}{c}\text { Nilai } \\
\text { Terendah }\end{array}$ & $\overline{\boldsymbol{X}}$ & $\mathbf{N}$ & $\mathbf{S}$ \\
\hline $\begin{array}{l}\text { Eksperimen } \\
\text { I }\end{array}$ & 94,87 & 66,67 & 86,30 & 32 & 7,72 \\
\hline $\begin{array}{l}\text { Eksperimen } \\
\text { II }\end{array}$ & 94,87 & 69,23 & 85,02 & 32 & 7,93 \\
\hline
\end{tabular}

Based on the description of the data in table 1 above, it is known that the average value of reading comprehension exposition text skills in experimental class I students taught with the AIR learning model is not much different than the experimental class II students who are taught with the brainstorming learning model, namely 86.30 experimental class I and experimental class II, which is 85.02. The average students in the experimental class I and experimental class II were above the KKM (the KKM standard set by the school for Indonesian subjects in class VIII MTsN 5 Solok Selatan was 75).

Based on the results of testing the first hypothesis, a tcount of 0.681 was obtained with a price greater than ttable $(0.681<1.671)$. This shows that there is no 
difference in the reading comprehension skills of exposition text between students who are taught with the AIR learning model and students who are taught with a brainstorming learning model. Students who are taught with the AIR learning model have average values that are not much different from students who are taught with the brainstorming learning model, so it can be said that the AIR learning model and the brainstorming learning model are effectively applied in learning the reading skills of exposition text comprehension.

Differences in Reading Skills Understanding Text Exposition Students Who Have High Reading Interest Taught by Using the AIR learning model and the Brainstorming Learning Model.

The results of the second hypothesis testing show that the reading comprehension skills of exposition text students who have high reading interest who are taught with the AIR learning model are no different from students who have high reading interest who are taught with the brainstorming learning model. The difference in reading comprehension skills of exposition text in students of experimental class I and experiment II who have high reading interest is also shown by the average value of reading comprehension skills of students' exposition text. The average value of experimental class I and experiment II can be seen in the table below.

Table 2 Reading Skills Test Results of Understanding Text Exposition Students Who Have Tiggi Reading Interest in Experiment Class I and Experiment Class II

\begin{tabular}{|l|c|c|c|c|c|}
\hline Kelas & $\begin{array}{c}\text { Nilai } \\
\text { Tertinggi }\end{array}$ & $\begin{array}{c}\text { Nilai } \\
\text { Terendah }\end{array}$ & $\overline{\boldsymbol{X}}$ & $\mathbf{N}$ & $\mathbf{S}$ \\
\hline $\begin{array}{l}\text { Eksperimen } \\
\text { I }\end{array}$ & 94,87 & 87,18 & 91,35 & 16 & 2,94 \\
\hline $\begin{array}{l}\text { Eksperimen } \\
\text { II }\end{array}$ & 94,87 & 84,62 & 90,70 & 16 & 3,36 \\
\hline
\end{tabular}

Based on the data description in table 2 above, the average value of reading comprehension text skills of exposition students of experimental class I who have high ability is 91.35 , while the average value of reading comprehension text skills of exposition students of experimental class II students who have high reading interest is 90.70 .

Differences in Reading Skills Understanding Text Exposition Students Who Have Low Reading Interest Taught by Using AIR Learning Models and Brainstorming Learning Models

The results of the third hypothesis testing showed that the reading comprehension skills of students' exposition texts having low reading interest taught with the AIR learning model were no different from students having low reading interest who were taught with the Brainstorming learning model. That is, the AIR learning model and the Brainstorming learning model do not influence the reading skills of students' understanding of text exposition who have low interest in reading experiment class I and experiment class II. The average value of experimental class I and experiment II can be seen in the table below.

Table 3 Reading Skills Test Results of Understanding Text Exposition Students Who Have Tiggi Reading Interest in Experiment Class I and Experiment Class II

\begin{tabular}{|c|c|c|c|c|c|}
\hline \multirow{2}{*}{ Kelas } & $\begin{array}{c}\text { Nilai } \\
\text { Tertin } \\
\text { ggi }\end{array}$ & $\begin{array}{c}\text { Nilai } \\
\text { Terendah }\end{array}$ & $\overline{\boldsymbol{X}}$ & $\mathbf{N}$ & $\mathbf{S}$ \\
\hline Eksperimen I & 89,74 & 66,67 & $\begin{array}{c}81,2 \\
3\end{array}$ & 16 & $\begin{array}{c}7,7 \\
6\end{array}$ \\
\hline Eksperimen II & 89,74 & 69,23 & 79,3 & 16 & $\begin{array}{c}7,0 \\
4\end{array}$ \\
\hline
\end{tabular}

Based on the data description in table 3 above, the average value of reading comprehension text skills of exposition students of experimental class I students who have low reading interest is 81.23 , while the average value of reading comprehension text skills of exposition students of experimental class II students who have interest in reading the low is 79.33 .

Interaction between the AIR learning model and the Brainstorming learning model with Interest in Reading in Affecting Reading comprehension skills in exposition text

The interaction between the AIR learning model and the brainstorming learning model with reading interest can also be seen from the results of the average reading skills test for exposition text comprehension. As seen in Figure 1 below.

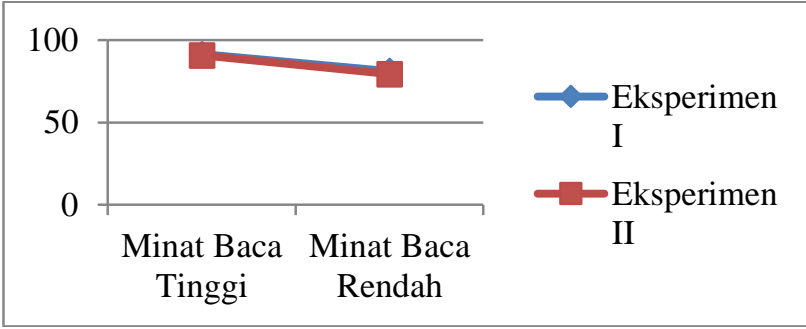

Picture 1. Interaction between the AIR learning model and the Brainstorming learning model with Interest in Reading Skills on reading comprehension exposition texts

Based on Figure 1, it can be seen that the group of experimental class I students who have high reading interest with an average value of 91.35 , the group of students of experimental class I who have low learning motivation with an average score of 81.23 , grade students Experiment II which has high learning motivation with an average value of 90.70, d students of Experiment II who have low learning motivation with an average value obtained 79.33. With the attached lines shown in Figure 1, it can be concluded that there is an effect of interaction between the learning model with students' interest in reading to reading comprehension text skills of students of class VIII MTsN 5 Solok Selatan.

From the results of data analysis, it can be seen that the AIR learning model significantly influences the 
students' reading comprehension text reading skills who have low reading interest compared to the brainstorming learning model. That is, students who have low interest in reading are better taught with the AIR learning model compared to the brainstorming learning model. However, both learning models, both AIR and brainstorming are equally effective in influencing reading skills in understanding text exposition students who have high reading interest.

\section{CONCLUSION}

There are four results of this study. First, there is no significant difference in reading exposition text skills between students taught using auditory, intellectually, repetition (AIR) learning models and students taught with brainstorming learning models, with an average comparison of the two classes of 86.30 and 85.02. Secondly, there is no significant difference in reading exposition text skills between students who have high reading interest who are taught with auditory learning models, intellectually, repetition (AIR) and students who have high reading interest taught with brainstorming learning models, with a comparison of the two averages the classes are 91.35 and 90.70. Third, there is no significant difference in reading exposition text skills between students who have low reading interest who are taught with auditory learning models, intellectually, repetition (AIR) and students who have low reading interest who are taught with brainstorming learning models, with a comparison of the average the two classes are 81.23 and 79.33. Fourth, there is a significant interaction effect between the learning model and students 'interest in reading to students' reading comprehension text skills.

So we can conclude, students who have low interest in reading are better taught with the AIR learning model compared to the brainstorming learning model. However, both learning models, both AIR and brainstorming are equally effective in influencing reading skills in understanding text exposition students who have high reading interest.

\section{ACKNOWLEDGMENTS}

In writing this research journal, the writer is guided and motivated by various parties. For this reason, the authors thank (1) Dr. Erizal Gani, M.Pd., as a supervisor, (2) Prof. Dr. Harris Effendi Thahar, M.Pd., and Dr. Abdurahman, M.Pd., as the examiner lecturer, (3) Mr. and Mrs. lecturers of the Indonesian and Regional Language and Literature Department, FBS UNP, (4) Teachers and teaching staff of MTsN 5 Solok Selatan, (5) Students of Class VIII MTsN 5 Solok South, and (6) friends who have provided motivation and support in writing this research journal.

\section{REFERENCES}

[1] Al-Issa, Ahmad. (2006). Schema theory and 12 reading comprehension: implications for teaching. Journal of College Teaching \& Learning. 3.
[2] Arikunto. (2008) . Dasar-dasar Evaluasi Pendidikan. Jakarta: Bumi Aksara.

[3] Budiyanto, Moch \&Agus Krisno. (2016). Sintaks 45 Model Pembelajaran dalam Student Centered Learning (SCL). Buku Ajar. Malang: Universitas Muhammadiyah Malang.

[4] Febriyanto, Budi. (2016) Penerapan model cooperative integrated reading and composition dalam pembelajaran keterampilan membaca pemahaman". Jurnal Cakrawala Pendas. 2(2).

[5] Hiller, Florian. (2013). Reading comprehension strategies: an international comparison of teacher preferences. Research in Comparative and International Educatio. 8(4).

[6] Huda, Miftahul. (2010). Model-model Pengajaran dan Pembelajaran. Yogyakarta: Pustaka Pelajar.

[7] Irianto, Agus. (2004). Statistik Pendidikan. Gadjah Mada: University Press.

[8] Karbalaei Alireza, Fatemeh Sanati. (2015). The study of the relationship between emotional intelligence, reading motivation, and anxiety with reading comprehension among iranian efl learners. International Journal of English Language and Literature Studies. 4(4), 171-183.

[9] Razak. (2005). Membaca Pemahaman Teori dan Aplikasi Pengajaran. Pekanbaru: Autografika.

[10]Ridwan, Abdul Sani. (2013). Inovasi Pembelajaran. Jakarta. PT. Bumi Aksara.

[11]Roestiyah. (2012). Strategi Belajar Mengajar. Jakarta: Rineka Cipta.

[12] Safitri, Devi Afiani, Siti Ngaisah. (2018). Pengaruh metode circ (cooperative integrated reading and composition terhadap kemampuan membaca pemahaman siswa pada materi cerita rakyat. Jurnal Keilmuan dan Pendidikan Dasar. 10 (1).

[13] Shoimin, Aris. (2010) 68 Model Pembelajaran Inovatif dalam Kurikulum 2013. Yogyakarta: ArRuzz Media.

[14] Soleimani Hassan, Sajadeh Hajghani. (2013). The effect of teaching reading comprehension strategies on iranian efl pre-university students' reading comprehension ability. International Research Journal of Applied and Basic Sciences. 5(5), 594-600.

[15] Tarigan, Henry Guntur. (2008). Menulis sebagai Suatu Keterampilan Berbahasa. Bandung: Angkasa.

[16] Tavakoli, Hossein. (2014). The effectiveness of metacognitive strategy awareness in reading comprehension: the case of iranian university efl students. Journal The Reading Matrix 2014.

[17] Winkel, Ws. (1996). Psikologi Pendidikan Evaluasi. Jakarta: Gramedia. 